\title{
THERMAL CONDUCTIVITY AND ELECTRICAL RESISTIVITY OF ZIRCALOY-4
}

\author{
prepared by \\ Allen D. Feith \\ Principal Engineer, Materials Evaluation
}

NUCLEAR SYSTEMS PROGRAMS

MISSILE AND SPACE DIVISION

GENERAL ELECTRICAL COMPANY

Cincinnati, Ohio 45215

October 1966

This work was sponsored by the Atomic Energy Commission under Contract Number AT (40-1)-2847.

\begin{abstract}
LEGAL NOTICE
This report was prepared as an account of Government sponsored work. Neither the United This report was prepared as an accoun person acting on behalf of the Commission:

A. Makes any warranty or representation, expressed or implied, with respect to the accuracy, completeness, or usefulness of the information contained in this report, or that the use of any information, apparatus, method, or process disclosed in this report may not infringe privately owned rights; or

B. Assumes any liabilities with respect to the use of, or for damages resulting from the use of any information, apparatus, method, or process disclosed in this report.

As used in the above. "person acting on behalf of the Commission" includes any employee or contractor of the Commission, or employee of such contractor, to the extent that such employee or contractor of the Commission, or employee of such contractor prepares, disseminates, or provides access to, any information pursuant to his employment or contract with the Commission, or his employment with such contractor.
\end{abstract}

This document is PUBLICLY RELEASABLE $R$ Stevila

Authorizing Official

Date: $\quad 9-20.06$ 


\section{DISCLAIMER}

This report was prepared as an account of work sponsored by an agency of the United States Government. Neither the United States Government nor any agency Thereof, nor any of their employees, makes any warranty, express or implied, or assumes any legal liability or responsibility for the accuracy, completeness, or usefulness of any information, apparatus, product, or process disclosed, or represents that its use would not infringe privately owned rights. Reference herein to any specific commercial product, process, or service by trade name, trademark, manufacturer, or otherwise does not necessarily constitute or imply its endorsement, recommendation, or favoring by the United States Government or any agency thereof. The views and opinions of authors expressed herein do not necessarily state or reflect those of the United States Government or any agency thereof. 


\section{DISCLAIMER}

Portions of this document may be illegible in electronic image products. Images are produced from the best available original document. 
The thermal conductivity of Zircaloy-4 was measured in a radial heat flow device. Results of these measurements indicate that the conductivity of this material increases with temperature from $0.16 \mathrm{w} / \mathrm{cm}^{\circ} \mathrm{C}$ at $400^{\circ} \mathrm{C}$ to $0.425 \mathrm{w} / \mathrm{cm}^{\circ} \mathrm{C}$ at $1500^{\circ} \mathrm{C}$. A platinum-platinum $+10 \%$ rhodium thermocouple was used as a probe for temperature measurements up to about $1150^{\circ} \mathrm{C}$ whereas an optical pyrometer was used above this temperature.

Electrical resistivity measurements were made from room temperature to $920^{\circ} \mathrm{C}$ using a rod specimen which was fabricated from the same raw material as the thermal conductivity specimens. Results of this study show that the electrical resistivity of Zircaloy-4 is considerably higher than essentially pure zirconium. The data indicate a maximum in resistivity of of $140.0 \times 10^{-6} \mathrm{ohm}-\mathrm{cm}$ at $810^{\circ} \mathrm{C}$ with a sharp decrease in resistivity as the material undergoes a phase change from hexagonal close packed $(\alpha)$ to the body centered cubic ( $(8)$ phase at $\sim 860^{\circ} \mathrm{C}$. 
Alloys of zirconium have proven to be valuable for structural and fuel cladding applications in nuclear reactors for many years due to their corrosion resistance in the heat transfer medium and their relatively low neutron absorption cross section. Thermal property data have been reported ${ }^{(1)}$ for pure zirconium and some of its alloys to $780^{\circ} \mathrm{C}$; however, very little, if any data exist above this temperature. The data described in this report are the results of our efforts to determine the thermal conductivity of Zircaloy-4 up to temperatures approaching its melting point $\left(\sim 1830^{\circ}-1845^{\circ} \mathrm{C}\right)$. This work was performed for the AEC High Temperature Materials Program in support of LOFT.

Although zirconium and its alloys exhibit excellent corrosion resistance and stability in the presence of other materials below $1000^{\circ} \mathrm{C}$, it reacts readily with most other materials at temperatures above $\sim 1200^{\circ} \mathrm{C}$. Its "gettering" properties for oxygen, nitrogen, hydrogen, etc., have been exploited in electronic component applications where it is employed as a getter in vacuum tubes to absorb small traces of these elements which may outgas from other components in the tube enclosure(1). Absorption of, and reactions with gases and other elements cause changes in the thermal and electrical properties of the material; therefore, property measurements on this material are very difficult. Zirconium also forms eutectics with refractory metals, i.e., molybdenum at $1520^{\circ} \mathrm{C}(1)$ and tungsten at $1650^{\circ} \mathrm{C}(1)$, which further increase the difficulties in making property measurements at high temperatures.

\section{APPARATUS}

The radial heat flow apparatus in which the thermal conductivity work was performed has been previously described in detail(2). A description of the four probe method for measuring electrical resistivity has a 1 so been reported ${ }^{(3)}$.

\section{SPECIMENS}

The thermal conductivity specimen and guard discs, as shown in Figure 1, were fabricated from $\mathrm{Zircaloy}-4$ plate, 0.75 inch thick and 9 inches square, which was purchased from Carborundum Metals Climax, Inc. as Zircaloy 4 , Grade 34 Zirconium (ASTM-B352-64T Grade RA2). Cylindrical rods $(0.635 \mathrm{~cm}$ diameter by $10.16 \mathrm{~cm}$ long) were machined from the same raw material and were used as electrical resistivity specimens. The rods had small holes through the diameter at a $7.5 \mathrm{~cm}$ spacing for voltage probes. Grooves near the ends of the rods accommodated the power leads. Small cubes (approximately $0.6 \mathrm{~cm}$ on a side) of Zircaloy-4 were placed in the furnace with the thermal conductivity specimens to monitor changes in composition due to high temperature exposure. The chemical composition of the material in the as-received condition is shown in Table 1 along with the composition after exposure in argon at high temperatures. It will be observed in Table 1 that the alloying constituents are very small in quantity; including impurities the additives total $1.14 \%$. 


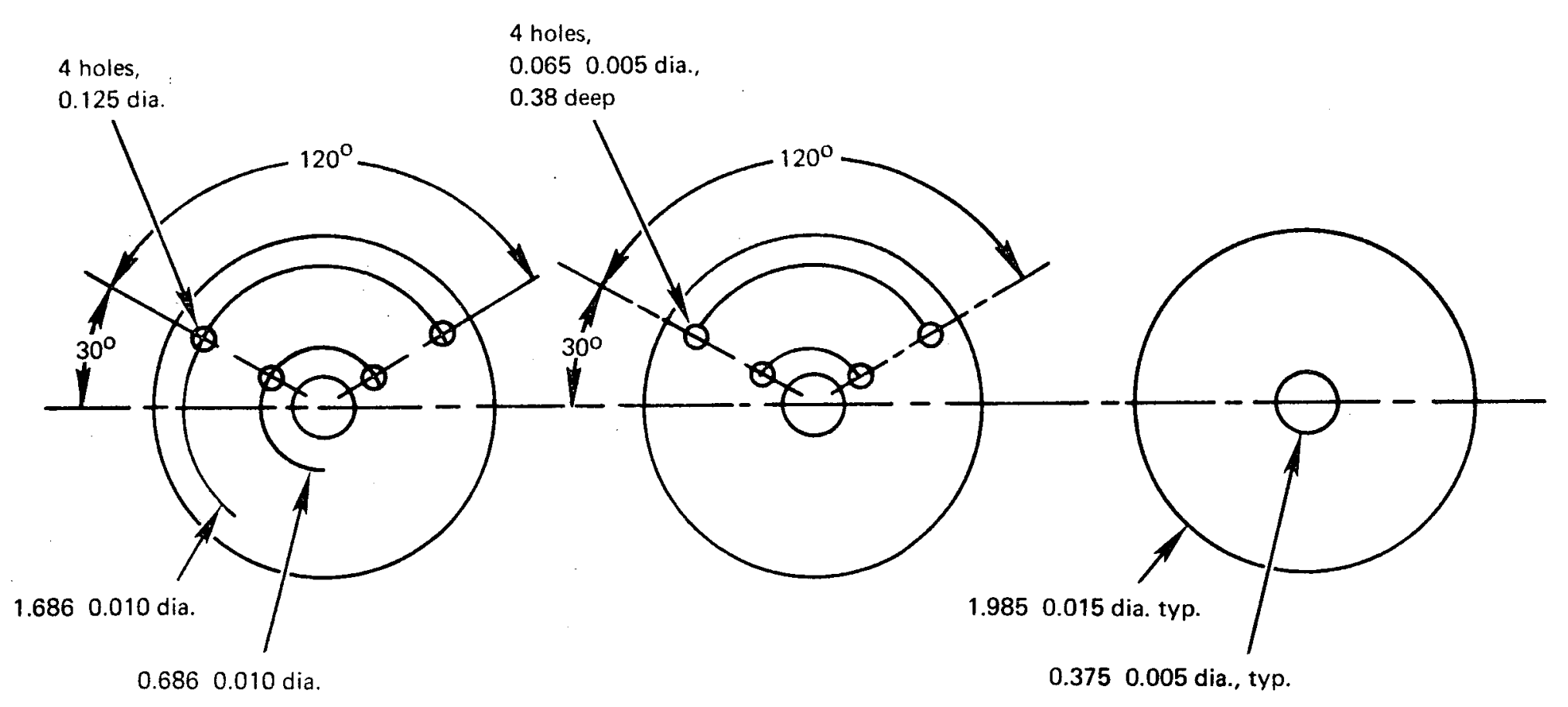

Upper guard

Specimen

Lower guard

Note: All dimensions are in inches. Thickness may be variable, however not less than 0.5 inch.

Figure 1 - Design of thermal conductivity specimens 
TABLE 1. COMPOSITION OF ZIRCALOY-4 THERMAL CONDUCTIVITY SPECIMENS (ppm except as noted)

As-Received

$\begin{array}{lc} & \\ \mathrm{C} & 38 \\ \mathrm{~N} 2 & 43 \\ \mathrm{Al} & 24 \\ \mathrm{~B} & <1 \\ \mathrm{Cd} & <7 \\ \mathrm{Co} & <10 \\ \mathrm{Cu} & 176 \\ \mathrm{Hf} & <100 \\ \mathrm{Mg} & 1600 \\ \mathrm{Mn} & 24 \\ \mathrm{Ni} & 12 \\ \mathrm{Si} & 24 \\ \mathrm{Ti} & 18 \\ \mathrm{~W} & <100 \\ \mathrm{Sn}^{\star} & 0.61 \% \\ \mathrm{Fe}^{\star} & 2300 \\ \mathrm{Cr}^{\star} & 860\end{array}$

Exposed

$100 \mathrm{Hrs} 400-800^{\circ} \mathrm{C} 200 \mathrm{Hrs} 400-1500^{\circ} \mathrm{C}$

37

42

27

$<1$

$<1$

$<10$

216

130

1500

32

7

28

19

$<100$

$1.16 \%$

2400

870
52

210

87

$<1$

$<1$

$<10$

153

$<100$

$<10$

13

7

46

$<10$

$<100$

$0.37 \%$

1900

815

\footnotetext{
*Alloying Constituents.
} 


\section{EXPERIMENTAL RESULTS}

\section{Therma1 Conductivity}

The results of the thermal conductivity measurements on Zircaloy-4 are shown in Figure 2 along with the least squares line reported by D. B. Scott (4). Scott estimates the accuracy of his method to be within 5 percent; however, the data from which his line was derived show scatter as high as \pm 10 percent. The spread in data presented herein is shown by the length of the bar at each point. The poorer precision at the higher temperatures is largely due to the small temperature gradient obtained $\left(\sim 15^{\circ} \mathrm{C}\right)$ and the difficulty in making small $\Delta \mathrm{T}$ determinations to high precision with an optical pyrometer; refractory metal thermocouples could not be considered due to the probable reactions of the specimen with the thermoelements and insulators at the higher temperatures. Data presented herein are reproducible since they represent measurements on two different specimens. Figure $2 \mathrm{~A}$ shows the deviation in conductivity between the average measured values and the smoothed line of Figure 2.

Repeated measurements were made below $860^{\circ} \mathrm{C}$, the $\alpha$ to $\beta$ phase transformation temperature, before going to higher temperatures in an attempt to determine the effect of the phase change on the thermal conductivity. If an effect exists it is probably within the scatter of these results. Table 2 is a complete list of measured values of thermal conductivity for several cycles of two different specimens. An examination of this table will reveal that the values are reproducible.

\section{Electrical Resistivity}

Measurements of electrical resistivity are normally more routine than are those of thermal conductivity. However, considerable difficulty was experienced with this material. Initially, the power leads and the voltage leads of pure zirconium wire were attached in a manner to insure good mechanical contact; measurements were made in argon at room temperature and at increasing temperatures to $920^{\circ} \mathrm{C}$ with small temperature intervals near the phase change. After the reading at $920^{\circ} \mathrm{C}$ was obtained, the voltage signal became very erratic and difficult to obtain. Upon shutdown and disassembly it was observed that a non-conducting film had formed on the voltage leads and on the thermocouple wires. This film was identified by radiographic techniques as $\mathrm{ZrO}_{2}$. The oxidation of the specimen was attributed to trace impurities of $\mathrm{O}_{2}$ or water vapor in the argon gas. These data are recorded in Table 3 as cycles 1,2 and 3 .

A second test was made after cleaning the specimen to remove loose surface contamination. The emf, thermocouple, and voltage leads were welded to the sample to assure a metallurgical bond and an uninterrupted signal if further contamination should occur. Measurements were made at room temperature in argon and helium and found to agree within one percent although about 2 percent higher than the initial measurements. The measurements at increasing temperatures followed the initial curve up to about $500^{\circ} \mathrm{C}$ where the second curve crosses the first (Figure 3 ). The maximum value was about $135 \times 10^{-6} \Omega-\mathrm{cm}$ at $808^{\circ} \mathrm{C}$ during the second run whereas it was about $140 \times 10^{-6} \Omega-\mathrm{cm}$ at $810^{\circ} \mathrm{C}$ during the first test. Data at $1150^{\circ} \mathrm{C}$ were considerably higher than anticipated when compared 


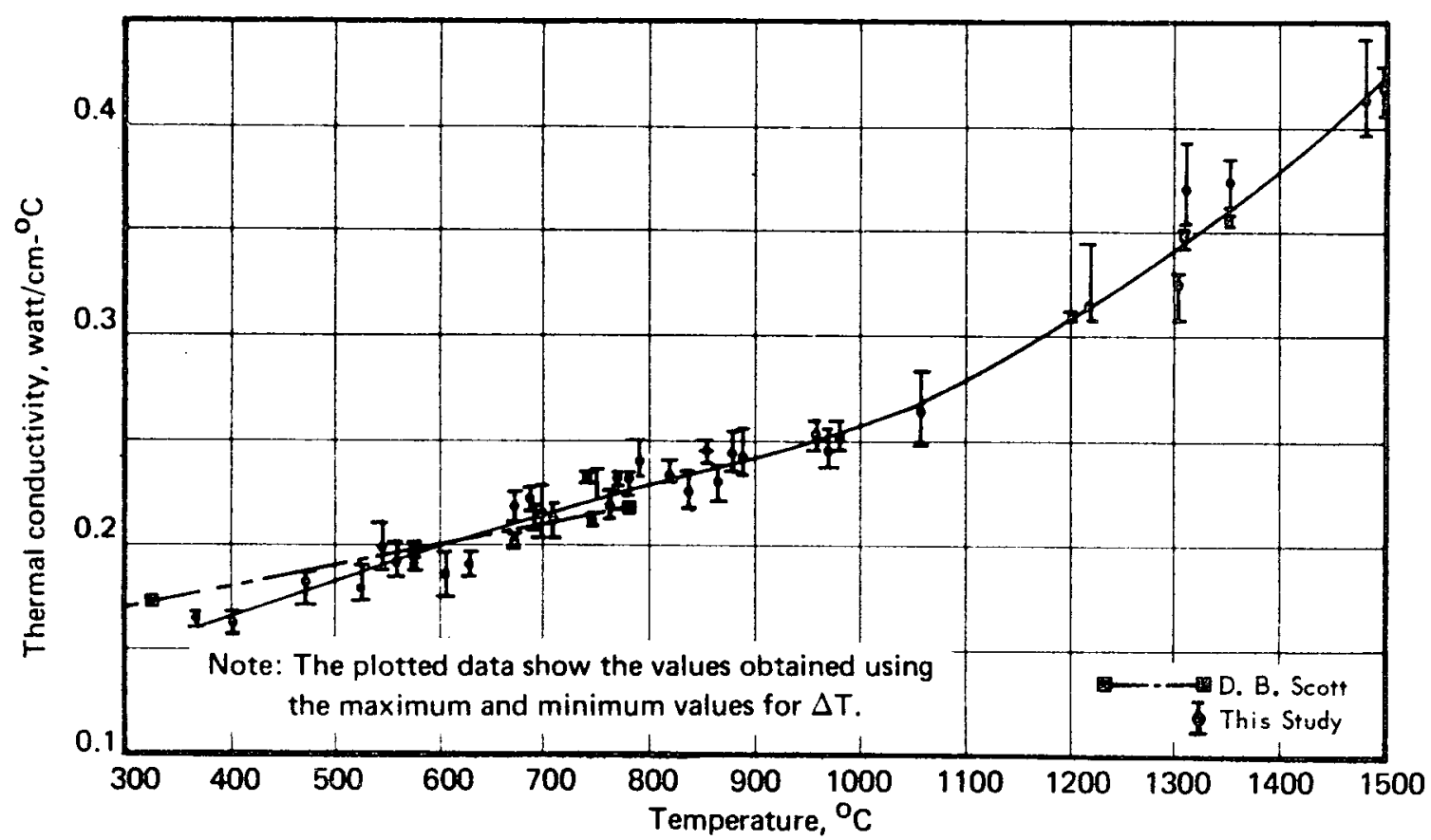

Figure 2 - Thermal conductivity vs. temperature for Zircaloy -4

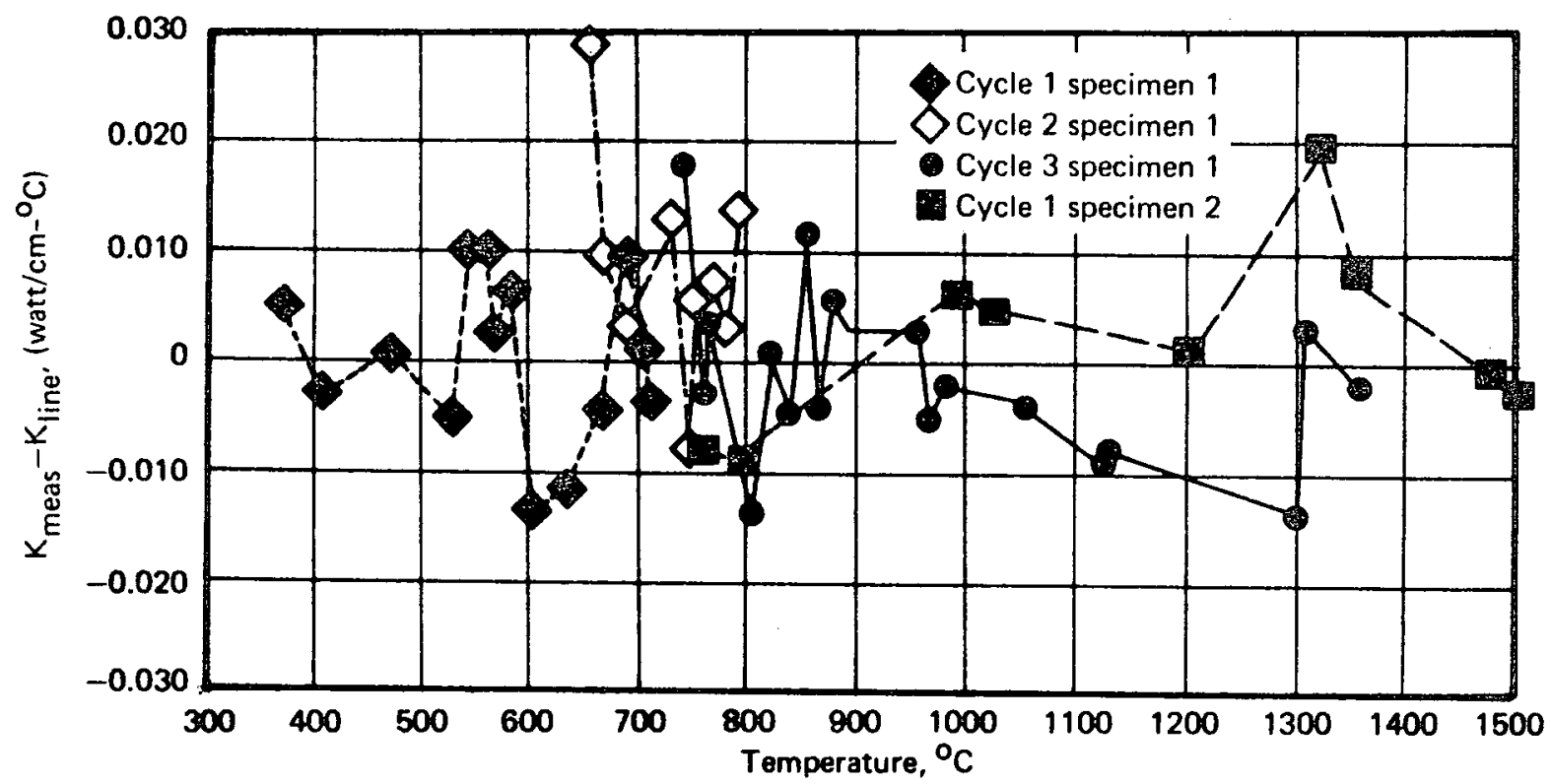

Figure $2 \mathrm{a}$ - Thermal conductivity of Zircaloy-4 deviation from smooth curve vs. temperature 
TABLE 2. THERMAL CONDUCTIVITY VALUES OF ZIRCALOY-4
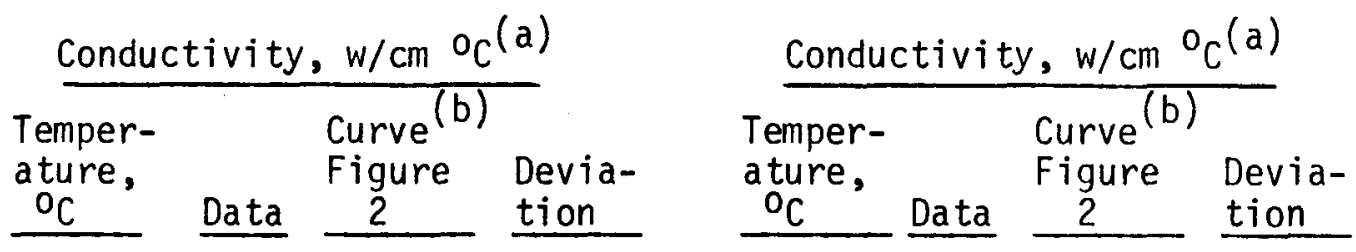

SPECIMEN NO. 1

\section{Cycle 1}

369

405

473

527

546

560

574

$577 \quad 0.200$

$607 \quad 0.184$

$\begin{array}{ll}629 & 0.190\end{array}$

$673 \quad 0.204$

0.158

$+0.005$

$0.164-0.003$

0.176

$0.175+0.001$

0.177

0.183

$-0.006$

$0.188+0.010$

$0.191+0.010$

0.193

$+0.003$

$+0.007$

$0.198 \quad-0.014$

$0.202-0.012$

$\begin{array}{ll}687 & 0.221\end{array}$

$0.208 \quad-0.004$

$\begin{array}{ll}696 & 0.214\end{array}$

$0.211+0.010$

708

$0.213+0.001$

$0.215-0.003$

(a) Each Conductivity Value is Calculated Using an Average of 5 Values for $\Delta T$.

(b) Values From Smoothed Line in Figure 2.

\section{Cycle 2}

$\begin{array}{llll}652 & 0.231 & 0.202 & +0.029\end{array}$

$\begin{array}{llll}670 & 0.218 & 0.208 & +0.010\end{array}$

$\begin{array}{llll}690 & 0.215 & 0.212 & +0.003\end{array}$

$\begin{array}{lllll}732 & 0.229 & 0.216 & +0.013\end{array}$

$\begin{array}{lllll}746 & 0.211 & 0.220 & -0.009\end{array}$

$\begin{array}{lllll}750 & 0.226 & 0.220 & +0.006\end{array}$

$\begin{array}{lllll}767 & 0.229 & 0.222 & +0.007\end{array}$

$\begin{array}{lllll}781 & 0.227 & 0.224 & +0.003\end{array}$

$\begin{array}{llll}790 & 0.240 & 0.226 & +0.014\end{array}$

(Table Continued on Page 9.) 
TABLE 2. THERMAL CONDUCTIVITY VALUES OF ZIRCALOY-4 (Cont'd)

\begin{tabular}{|c|c|c|c|c|c|c|c|}
\hline \multicolumn{4}{|c|}{ Conductivity, $w / \mathrm{cm}{ }^{\circ} \mathrm{C}(\mathrm{a})$} & \multicolumn{4}{|c|}{ Conductivity, $\mathrm{w} / \mathrm{cm}{ }^{\circ} \mathrm{C}(\mathrm{a})$} \\
\hline $\begin{array}{l}\text { Temper- } \\
\text { ature, } \\
{ }^{\circ} \mathrm{C} \\
\end{array}$ & Data & $\begin{array}{l}\text { Curve } \\
\text { Figure } \\
2 \quad \\
\end{array}$ & $\begin{array}{l}\text { Devia- } \\
\text { tion } \\
\end{array}$ & $\begin{array}{l}\text { Temper- } \\
\text { ature, } \\
{ }^{0} \mathrm{C} \\
\end{array}$ & Data & $\begin{array}{l}\text { Curve } \\
\text { Figure } \\
2 \\
\end{array}$ & $\begin{array}{l}\text { Devia- } \\
\text { tion } \\
\end{array}$ \\
\hline \multicolumn{4}{|c|}{ SPECIMEN NO. 1} & \multicolumn{4}{|c|}{ SPECIMEN NO. 2} \\
\hline \multicolumn{4}{|c|}{ Cycle 3} & \multicolumn{4}{|c|}{ Cycle 1} \\
\hline 739 & 0.236 & 0.218 & +0.018 & 748 & 0.212 & 0.220 & -0.008 \\
\hline 762 & 0.218 & 0.221 & -0.003 & 793 & 0.217 & 0.226 & -0.009 \\
\hline 764 & 0.225 & 0.221 & +0.004 & 996 & 0.262 & 0.255 & +0.007 \\
\hline 806 & 0.214 & 0.228 & -0.014 & 1016 & 0.265 & 0.260 & +0.005 \\
\hline 820 & 0.233 & 0.232 & +0.001 & 1211 & 0.311 & 0.310 & +0.001 \\
\hline 839 & 0.225 & 0.230 & -0.005 & 1321 & 0.368 & 0.348 & +0.020 \\
\hline 855 & 0.245 & 0.233 & +0.012 & 1352 & 0.373 & 0.365 & +0.008 \\
\hline 866 & 0.231 & 0.236 & -0.005 & 1482 & 0.414 & 0.415 & -0.001 \\
\hline 879 & 0.244 & 0.238 & +0.006 & 1498 & 0.418 & 0.420 & -0.002 \\
\hline 888 & 0.242 & 0.239 & +0.003 & & & & \\
\hline 959 & 0.253 & 0.250 & +0.003 & \multicolumn{4}{|c|}{ Cycle 2} \\
\hline 970 & 0.247 & 0.252 & -0.005 & 752 & 0.232 & 0.220 & +0.012 \\
\hline 980 & 0.252 & 0.254 & -0.002 & & & & \\
\hline 1058 & 0.264 & 0.268 & -0.004 & 1235 & 0.317 & 0.320 & -0.003 \\
\hline 1128 & 0.278 & 0.287 & -0.009 & & & & \\
\hline 1131 & 0.279 & & -0.008 & & & & \\
\hline 1303 & 0.326 & 0.342 & -0.014 & & & & \\
\hline 1308 & 0.346 & & +0.004 & & & & \\
\hline 1351 & 0.363 & 0.365 & -0.002 & & & & \\
\hline
\end{tabular}


TABLE 3. ELECTRICAL RESISTIVITY VALUES FOR ZIRCALOY-4

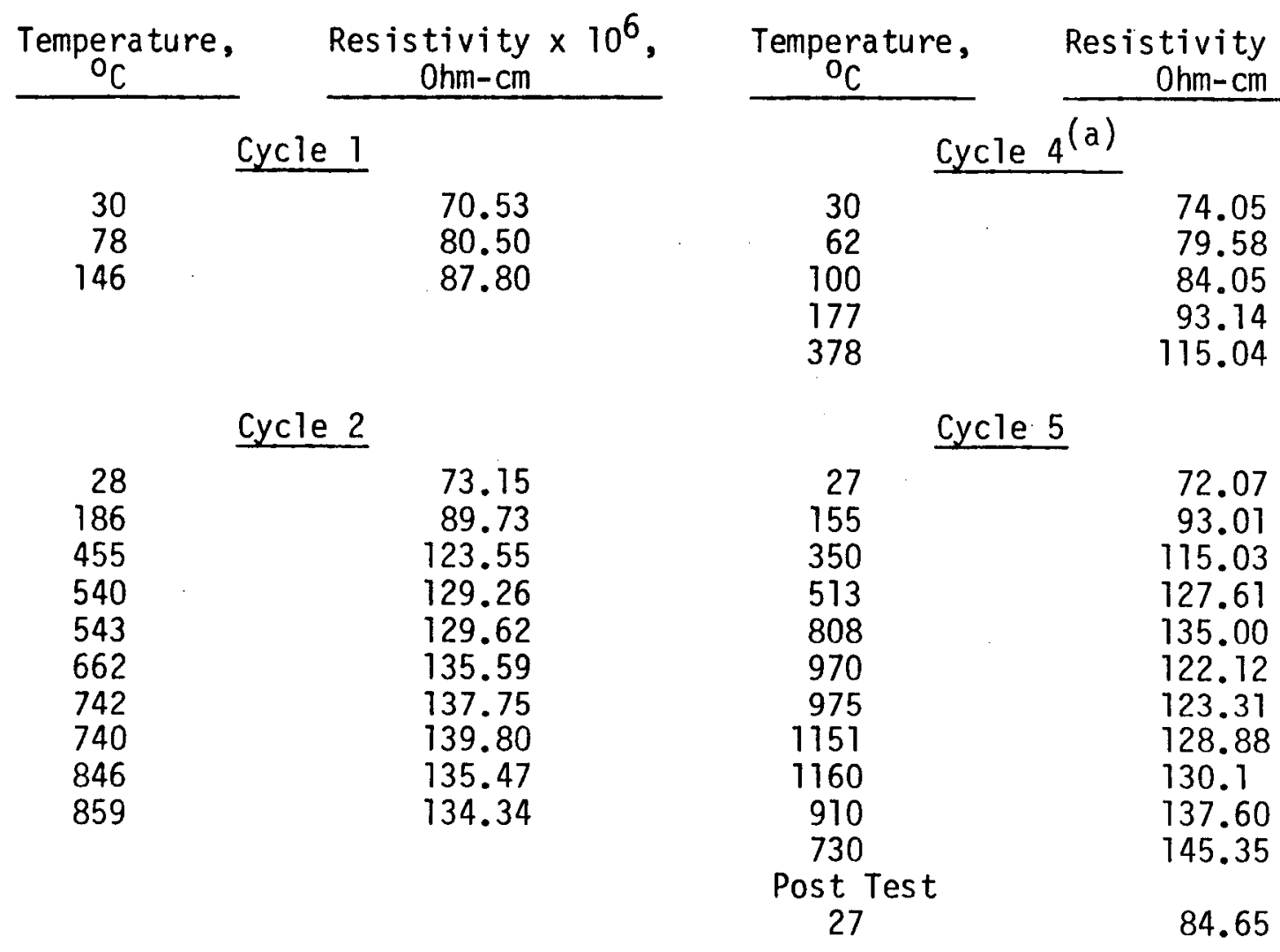

Cycle 3

694

810

814

920

137.47

140.47

136.45

116.36

As Received

Exposed $(b)$

$\frac{T,{ }^{\circ} \mathrm{C}}{19.6}$

Resistivity $\times 10^{6}$,

$0 \mathrm{hm}-\mathrm{cm}$

70.24

37.65

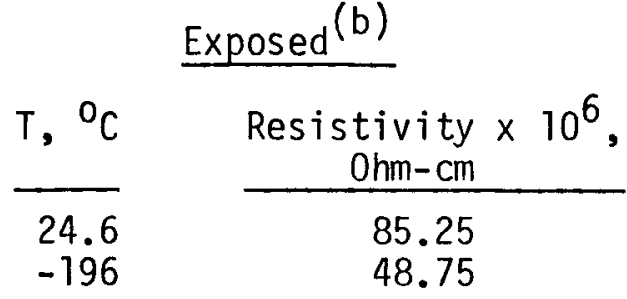

(a) NOTE: The Specimen was Removed and Cleaned Prior to Cycle 4. (b) Measurements After Cycle 5. 


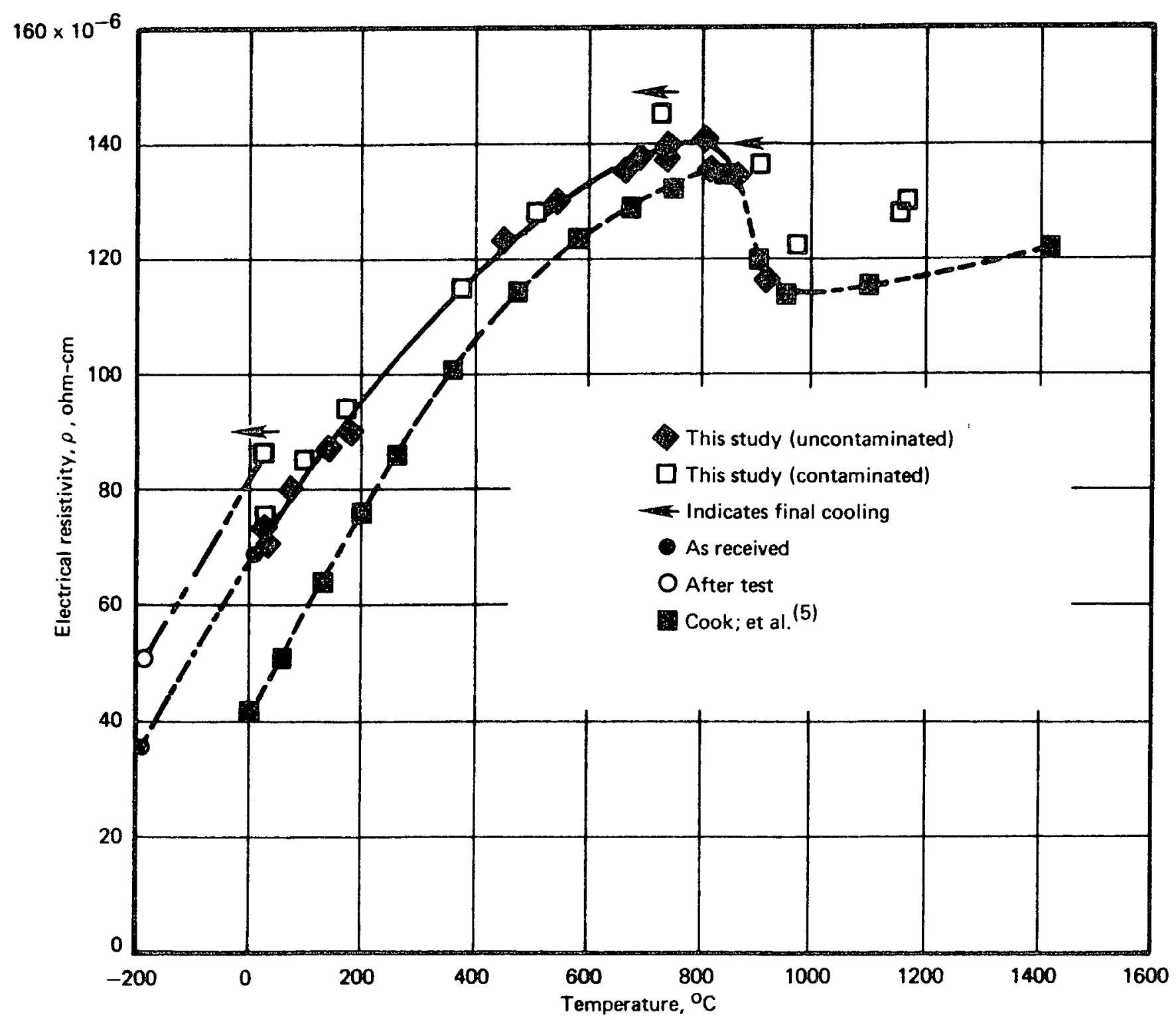

Figure 3 - Electrical resistivity as a function of temperature for Zircaloy-4 
to literature values of Cook, et al. (5) for his high hafnium $(1.8 \% \mathrm{Hf})$ sample. During cool down, measurements were made at $910^{\circ} \mathrm{C}, 730^{\circ} \mathrm{C}$ and room temperature. These data are considerably higher than the data on heating having a maximum of about $145 \times 10^{-6} \Omega-\mathrm{cm}$ at $730^{\circ} \mathrm{C}$; the room temperature value was increased by more than 10 percent over the initial value. The data are tabulated in Table 3 as cycles 4 and 5 and shown in Figure 3 with those of the previously cited literature (5). Suspecting that either additional contamination or diffusion of the oxygen from the outer surface through the diameter (or both) caused the change in resistivity, new measurements were made at room temperature and at liquid nitrogen temperature on this specimen and one which had not been exposed to high temperatures. These data, obtained in a different four probe apparatus, are also shown in Figure 3 and tabulated at the bottom of Table 3 and show a similar change in resistivity of the exposed material compared to the as-received specimen. This type of measurement is used routinely to identify changes in composition and effects of reactor environments on structural materials. Metallographic specimens were prepared and are shown in Figure 4. The as-received material is a homogeneous structure with the major phase believed to be basically zirconium containing a fine metallic appearing precipitate uniformly dispersed throughout the matrix. The photomicrograph of the exposed specimen indicates that considerable changes have taken place in this material. A dense layer, approximately 0.006 inch thick, which appears to be oxygen rich $\alpha$ zirconium surround a uniform 2 or 3 phase structure similar to the as-received material but containing large "islands" rather than finely dispersed particles of the precipitate. A diamond point hardness of 572 was measured in the outer layer compared to 300 in the core. This large difference in hardness is attributed to oxygen absorption into the surface layer. $X$-ray powder patterns revealed no change in the lattice parameters as a result of the exposure during measurement. The 0.006 inch thick surface layer, if uniform, represents about $9.4 \%$ of the cross section area of the specimen. The change in resistivity which amounted to about $4 \%$ at $730^{\circ} \mathrm{C}$ and about $18 \%$ at room temperature may be due to the oxide layer if the surface layer has a considerably higher resistivity than does the Zircaloy-4. The third photomicrograph in Figure 4 shows the effect of exposure to $1500^{\circ} \mathrm{C}$ in argon during the thermal conductivity measurements. Although the color of the surface was blue after exposure, no oxide film can be observed. 

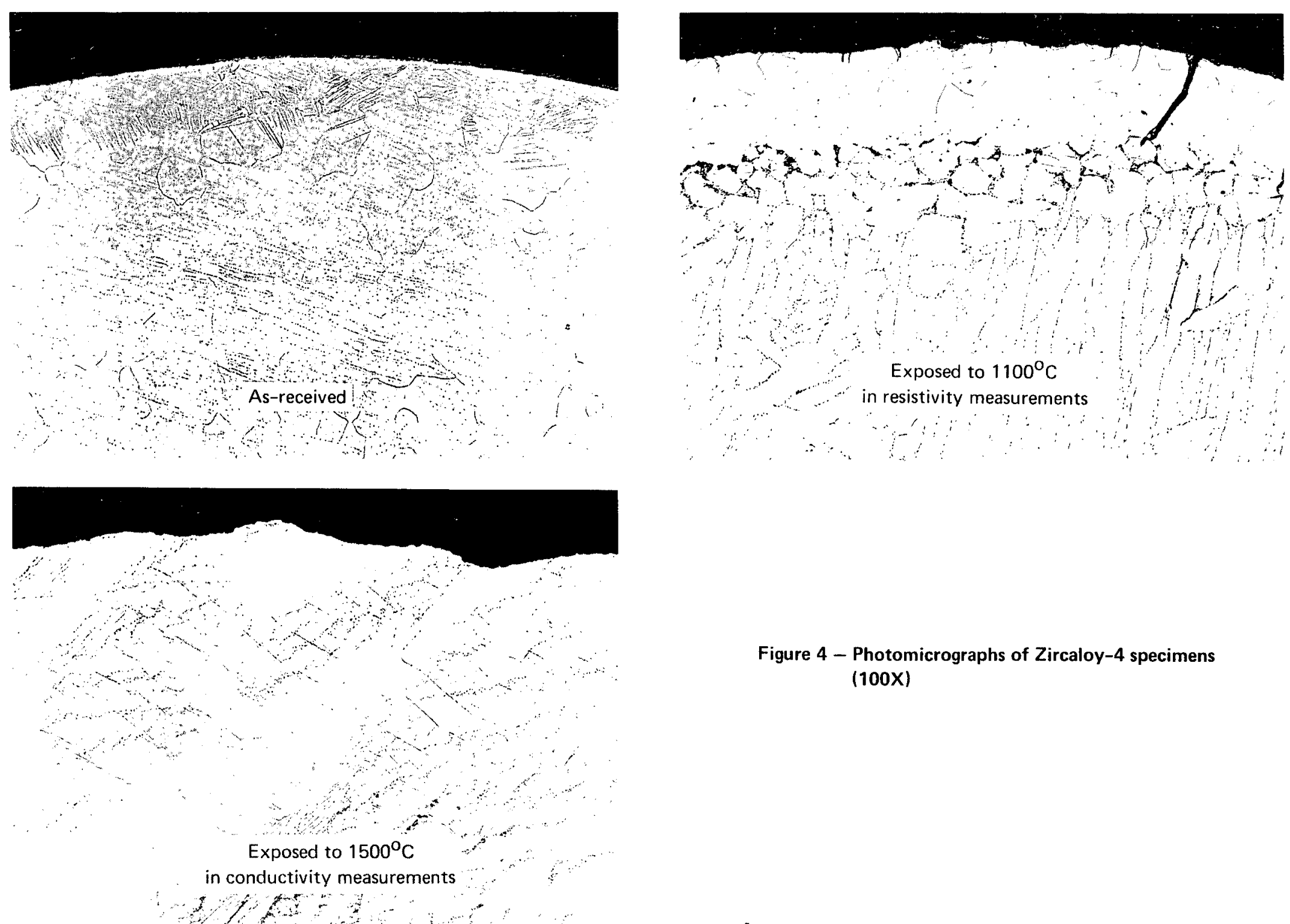

Figure 4 - Photomicrographs of Zircaloy-4 specimens $(100 \mathrm{X})$ 


\section{DISCUSSION OF RESULTS}

The thermal conductivity data for $\alpha$ phase (hcp) Zircaloy-4 appear to contain a lattice component on the order of 10 percent of the total conductivity. Almost 100 percent of the conductivity in the $B$ phase (bcc) appears to be electronic. Conclusions such as these are based on the curves shown in Figure 5. The total conductivity from the smooth curve in Figure 2 has been replotted along with the calculated values of the electronic conductivity from (Table 4) the equation:

$$
k_{e}=\frac{L T}{\rho}
$$

where

$$
\begin{aligned}
& \mathrm{k}_{\mathrm{e}}=\text { electronic component of thermal conductivity }\left(\text { watt } / \mathrm{cm}{ }^{\circ} \mathrm{K}\right) \\
& \mathrm{L}=\text { Lorenz number }=2.45 \times 10^{-8} \text { watt ohm } /{ }^{\circ} \mathrm{K}^{2} \\
& \mathrm{~T}=\text { absolute temperature, }{ }^{\circ} \mathrm{K} \\
& \mathrm{O}=\text { electrical resistivity, ohm-cm }
\end{aligned}
$$

The values above $920^{\circ} \mathrm{C}$ were obtained by using the resistivity data of cook ${ }^{(5)}$; however, its use may lead to an erroneous comparison since the composition is different. It has been shown generally that the electrical resistivity of an element increases as impurities or alloying constituents are increased. It is quite possible that the resistivity of 8 phase Zircaloy -4 may be higher than that reported by Cook for the high hafnium sample; therefore, some displacement between these two curves may occur in the $\beta$ phase regions. The rise in the electronic component between $850^{\circ}$ and $900^{\circ} \mathrm{C}$ is due to the sharp decrease in electrical resistivity as the material transforms from the hexagonal close packed $\alpha$ structure to the body centered cubic structure of the $\beta$ phase.

As stated earlier, it is highly possible that the scatter in the thermal conductivity data may have obscured a change in conductivity at the phase change unless the phonon contribution from the body centered cubic structure is considerably less than that of the hexagonal close packed structure. At this time it is difficult to draw any conclusions from the data above $1200^{\circ} \mathrm{C}$ due to the difficulties in measurements of conductivity and the lack of electrical resistivity data for this particular material.

Calculation of the Lorenz number at various temperatures from the thermal conductivity and the electrical resistivity data gives the results shown in Figure 6 and Table 5. These values again indicate a phonon contribution in the $\alpha$ phase since the calculated Lorenz number is greater than the theoretical constant but virtually no phonon contribution in the 8 phase (above $862^{\circ} \mathrm{C}$ ).

Changes in chemical composition during the thermal conductivity measurements which are shown in Table 1 are significant only in the increase in nitrogen, decrease in tin, and the loss of virtually all of the magnesium. It is felt that these small changes in composition did not 


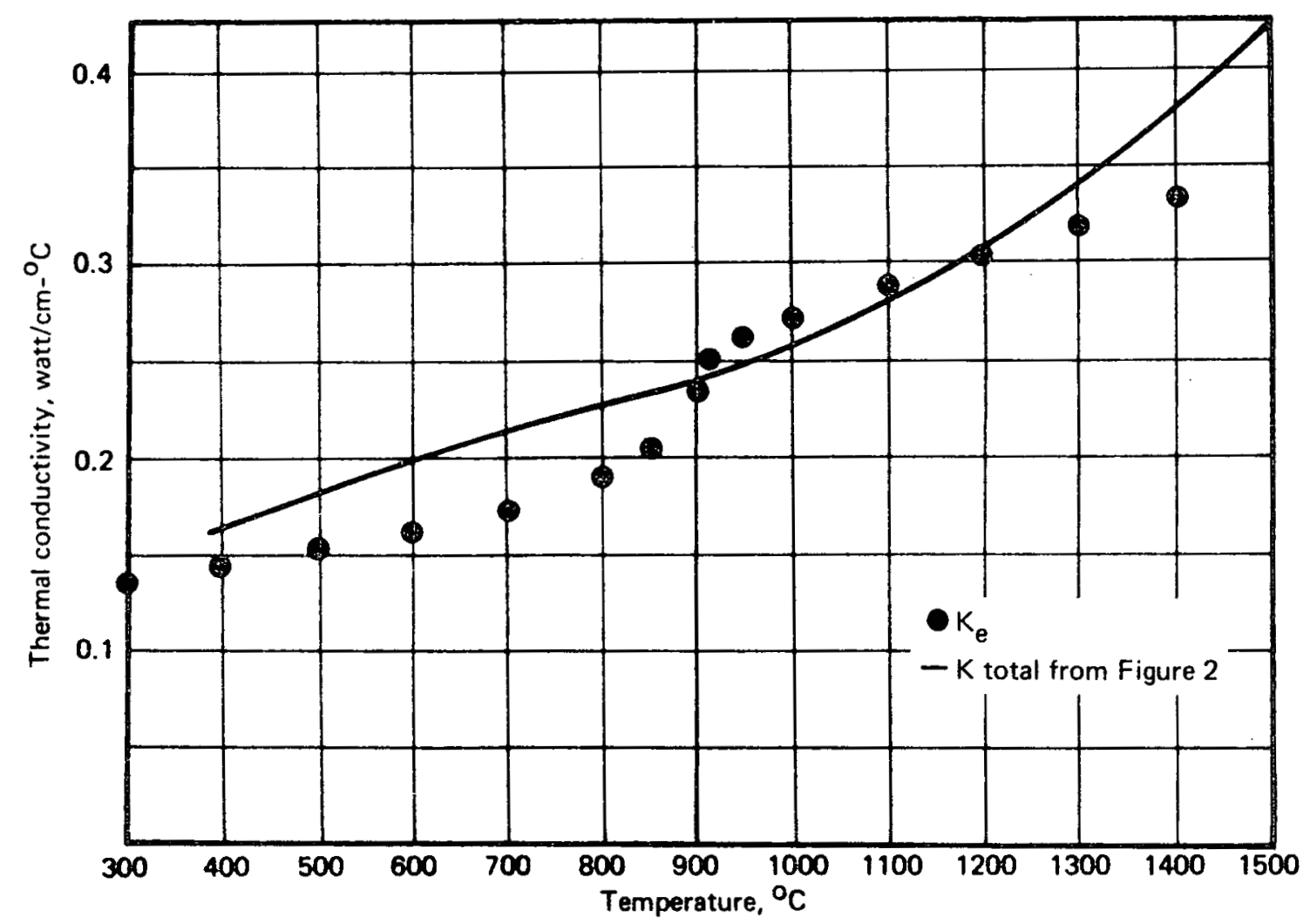

Figure 5 - Total thermal conductivity and electronic conductivity as a function of temperature for Zircaloy-4

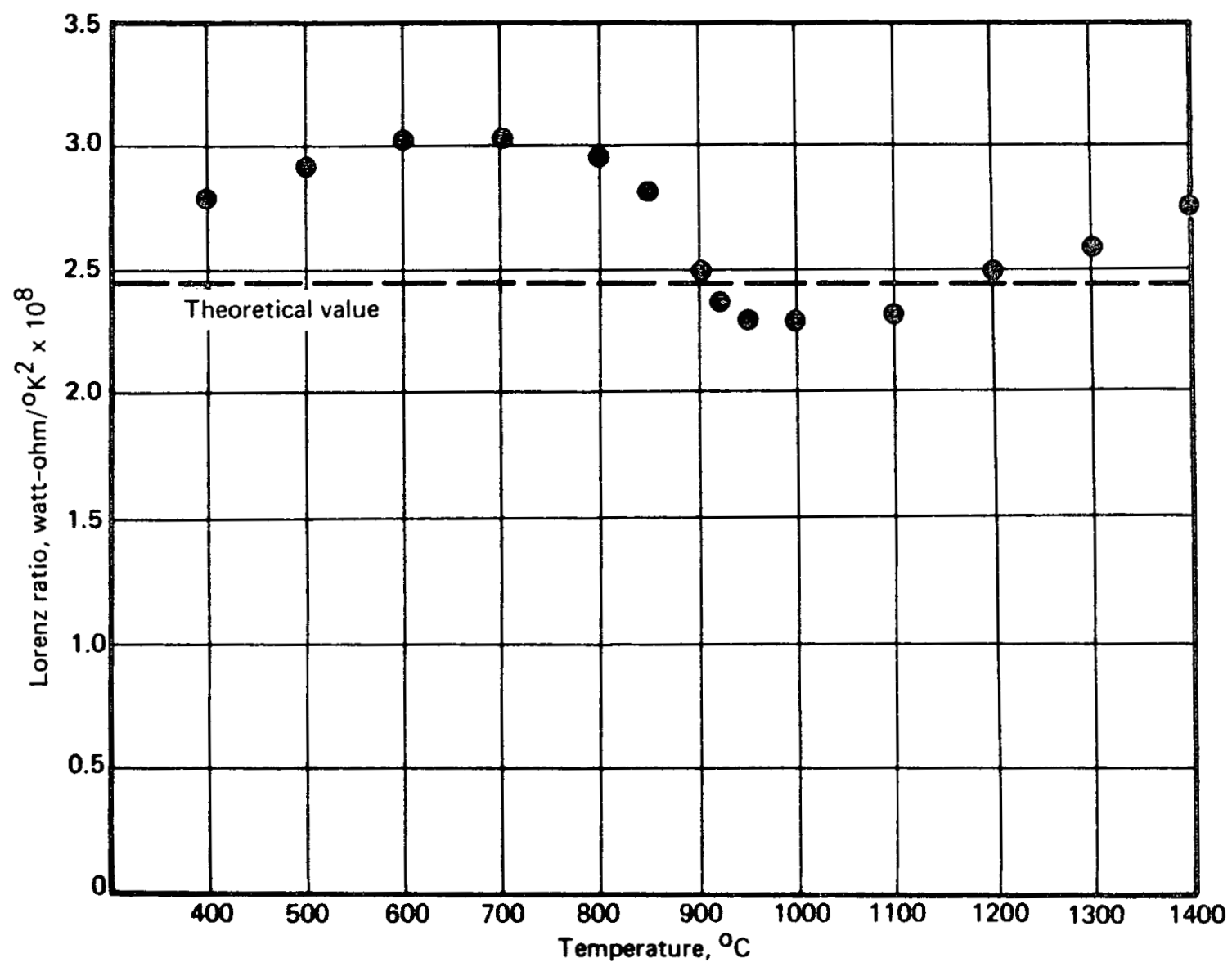

Figure 6 - Lorenz ratio $\mathrm{K} \rho / \mathrm{T}$ as a function of temperature for Zircaloy -4 
TABLE 4. CALCULATED VALUES OF $k_{e}$ FOR ZIRCALOY-4

\begin{tabular}{|c|c|c|}
\hline Temperature $\left({ }^{\circ} \mathrm{C}\right)$ & $\rho(\mathrm{ohm}-\mathrm{cm})$ & $\mathrm{k}_{\mathrm{e}}\left(\right.$ watt $\left./ \mathrm{cm}{ }^{\circ} \mathrm{C}\right)$ \\
\hline 20 & $72.0 \times 10^{-6}$ & 0.0997 \\
\hline 100 & 84.0 & 0.1088 \\
\hline 200 & 93.5 & 0.1239 \\
\hline 300 & 105.0 & 0.1337 \\
\hline 400 & 115.5 & 0.1428 \\
\hline 500 & 125.5 & 0.1513 \\
\hline 600 & 133.0 & 0.1608 \\
\hline 700 & 138.0 & 0.1727 \\
\hline 800 & 139.0 & 0.1891 \\
\hline 850 & 134.0 & 0.2503 \\
\hline 900 & 122.5 & 0.2346 \\
\hline 920 & 116.5 & 0.2509 \\
\hline 950 & 114.0 & 0.2628 \\
\hline $1000^{*}$ & 114.0 & 0.2736 \\
\hline $1100^{\star}$ & 116.0 & 0.2900 \\
\hline $1200^{\star}$ & 118.0 & 0.3058 \\
\hline $1300^{\star}$ & 120.0 & 0.3211 \\
\hline $1400^{*}$ & $122.0 \times 10^{-6}$ & 0.3360 \\
\hline
\end{tabular}


TABLE 5. CALCULATED LORENZ NUMBERS FOR ZIRCALOY-4

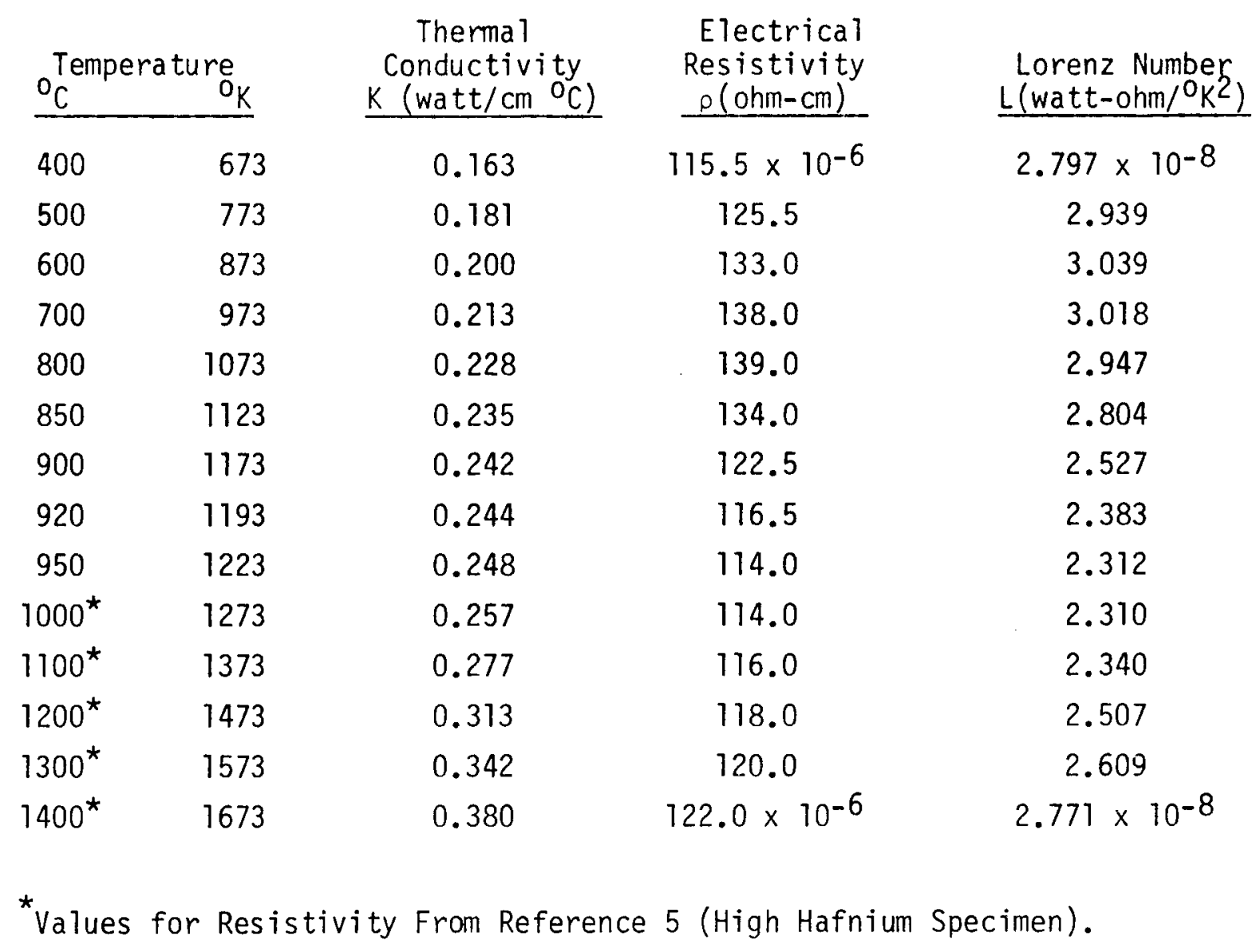


affect the thermal conductivity. However, small changes in composition which may affect the $\alpha$ to $\beta$ phase transformation may also affect the electrical resistivity. It should be noted that the chemical analyses in Table 1 were performed on samples which were exposed during the thermal conductivity measurements and that similar changes would be expected in the resistivity specimen due to the similarity in test environment. The conductivity specimens showed signs of surface oxidation in that their color changed from its normal metallic gray to shades of blue and gold typifying an oxide coating of varying thickness.

\section{CONCLUSIONS AND RECOMMENDATIONS}

Preliminary values for the thermal conductivity of $\mathrm{Zircaloy}-4$ over the temperature range of $400^{\circ}$ to $1500^{\circ} \mathrm{C}$ have been presented. The absence of other high temperature data for this material makes it difficult to evaluate its relative accuracy; however, it has been shown to be reproducible. Electrical resistivity data for $\alpha$ phase Zircaloy-4 have been presented; the data for the $B$ phase of this material is inconclusive due to contamination.

If further measurements are to be made on Zircaloy-4 on either thermal conductivity or electrical resistivity especially at high temperatures (up to $1700^{\circ} \mathrm{C}$ ), problems of contamination and eutectic formations between the specimen and refractory metals of the apparatus will have to be solved or circumvented. 
1. Lustman, B. and Kerze, F., Jr., "The Metallurgy of Zirconium," McGraw-Hill, (1965), pp. 359, 16, 26, 464 and 478 .

2. Feith, A. D., "A Radial Heat Flow Apparatus for High Temperature Thermal Conductivity Measurements," GEMP 296, General Electric, NMPO, (August 1963).

3. Feith, A. D., "Measurements of the Thermal Conductivity and Electrical Resistivity of Molybdenum," GE-TM 65-10-10, General Electric, NMPO, (October 1965).

4. Scott, D. B., "Physical and Mechanical Properties of Zircaloy-2 and 4," WACP 3269-41, Westinghouse Electric Corp., (May 1965).

5. Cook, L. A., Castleman, L. S. and Johnson, W. S., "Preliminary Report on Electrical Resistivity of Zirconium," WAPD-25, Westinghouse Electric Corp., (December 1950). 